\title{
RAPID AND ECONOMICAL QUANTITATIVE DETERMINATION OF SEVERAL ANTIHYPERTENSIVE AGENTS IN PRESENCE OF HYDROCHLOROTHIAZIDE BY ISOCRATIC REVERSED-PHASE HIGH-PERFORMANCE LIQUID CHROMATOGRAPHY IN THEIR PHARMACEUTICAL PREPARATIONS
}

\section{PANCHUMARTHY RAVISANKAR ${ }^{1 *}$, DEVALA RAO G ${ }^{2}$, MD. SHAHEEM SULTHANA ${ }^{1}$, SUPRIYA ${ }^{1}$, MOUNIKA G, NAVEENA $P^{1}$}

${ }^{1}$ Department of Pharmaceutical Analysis and Quality Assurance, Vignan Pharmacy College, Vadlamudi, Guntur, Andhra Pradesh, India. ${ }^{2}$ Department of Pharmaceutical Analysis, KVSR Siddhartha College of Pharmaceutical Sciences, Vijayawada, Andhra Pradesh, India

Received: 25 March 2017, Revised and Accepted: 22 August 2017

\section{ABSTRACT}

Objective: Objective of the present investigation is to develop a speedy isocratic reverse phase high-performance liquid chromatography (RPHPLC) method for the separation and quantitative determination of 5 angiotensin II - receptor antagonists, namely, telmisartan, losartan, valsartan, olmesartan, irbesartan, and atenolol along with thiazide diuretics mostly hydrochlorothiazide (HCTZ).

Methods: RP-HPLC method was evolved using Welchrom $\mathrm{C}_{18}$ column $(4.6 \times 250 \mathrm{~mm}, 5 \mu \mathrm{m})$ as a stationary phase with the mobile phase comprising a variety of phosphate buffer with $\mathrm{pH}-3.3$ and acetonitrile in the proportion of $50: 50 \mathrm{v} / \mathrm{v}$. The mobile phase was pumped at a current rate of $1 \mathrm{~mL} / \mathrm{minute}$. The detection wavelength was carried out at $230 \mathrm{~nm}$.

Results: The total run time was 6 minutes and the elution window of only 3 minutes. The peaks were eluted with decorous resolution. The calibration curves were linear $\left(r^{2}=0.9998\right)$ in all cases. The percentage relative standard deviation (RSD\%) was $<2 \%$ and average recovery was above $99.95 \%$. The method was validated specificity, precision, and accuracy. High recovery values and low RSD\% prove that this method is very accurate and reproducible. The developed method was applied to the estimation of the above-said drugs in binary combinations from different manufacturers which were a good agreement with label claim.

Conclusion: The important advantage of developed method was that the five individual drugs can be determined on a single chromatographic system without alteration in detection wavelength and mobile phase composition. This novel method was statistically validated as per ICH guidelines. The optimized method proved to be linear, accurate, and robust. Hence, the above said proposed method was found to be a rapid tool for the routine determination of the above-said drugs in alone or combination with HCTZ in quality control analysis without interference of excipients.

Keywords: Telmisartan, Losartan, Valsartan, Olmesartan, Irbesartan, Atenolol, Reversed-phase high-performance liquid chromatography.

(c) 2017 The Authors. Published by Innovare Academic Sciences Pvt Ltd. This is an open access article under the CC BY license (http://creativecommons. org/licenses/by/4. 0/) DOI: http://dx.doi.org/10.22159/ajpcr.2017.v10i12.18714.

\section{INTRODUCTION}

Angiotensin antagonists are the first major innovation in essential hypertension management as a first-line treatment. Antihypertensive agents are a largest drug class and hold a major share of the drug market, as hypertension is a major cause of health problems. Hydrochlorothiazide (HCTZ) acts on both RAS and sympathetic nerve system, thereby creating greater sensitivity to angiotensin receptor blockade (ARBs). This HCTZ is a good selection for use in combination with ARBs. ACE inhibitors are having major problems of cough, when compared to ARBs. All the existing ARBs and atenolol (ATEN) are in fixed-dose combination with HCTZ. According to the available present knowledge, no unique single reversed-phase high-performance liquid chromatography (RP-HPLC) method available for the determination of 5 angiotensin II-receptor antagonists, i.e. ATEN, telmisartan (TELM), losartan (LOSA), valsartan (VALS), olmesartan (OLME), and irbesartan (IRBE) along with thiazide diuretics mostly HCTZ. The present proposed method will help in determination of drugs in a single run, which reduces the analysis time and does not necessarily any separate method for each drug and combined tablet formulation. After a meticulous survey of literature reveals that there were some analytical methods have been reported for the determination of the drugs either individually or in combination with some additional drugs in tablet dosage forms and biological samples based on a wide variety of instruments such as spectrophotometric method [1], capillary electrophoresis [2], HPLC [3-16], LC-mass spectrometry (MS) [17,18], and LC-MS/MS [19-21]. Keeping in view of the complete evaluation the authors aim to develop a novel, simple, accurate, and sensitive method to determine combinations such as HCTZ with ATEN, HCTZ with TELM, HCTZ with LOSA, HCTZ with VALS, HCTZ with OLME, and HCTZ with IBRE without altering the detection wave length and chromatographic conditions.

\section{METHODS}

The above said standard drugs were gifted from Hetero Labs Ltd., Hyderabad, India. All other chemicals used in this method were purchased from Merck Chemical Division Ltd., Mumbai. HPLC grade acetonitrile, water, methanol, and triethylamine were obtained from Merck Pharmaceuticals Private Ltd., Mumbai, India. Commercial tablets of the above said formulation were procured from local pharmacies.

\section{Apparatus and instruments}

RP-HPLC was done on an isocratic HPLC (Shimadzu LC-20AT prominence LC) with a LC-20AT pump, manual Rheodyne injector with a loop volume of $20 \mu \mathrm{l}$, variable wavelength Shimadzu SPD-20 A prominence ultraviolet (UV) detector, and Welchrom $\mathrm{C}_{18}$ Column $(4.6 \times 250 \mathrm{~mm}, 5 \mu \mathrm{m}$ particle size). The HPLC system was set with "Spin chrome" software. An electronic balance (Shimadzu TX223L), digital PH meter (Systronics model - 802), a sonicator (spectral lab, model 
UCB 40), and UV-Visible spectrophotometer (Systronics model-2203) were used in this analysis.

\section{Preparation of $\mathrm{pH} 3.3$ phosphate buffer}

A $10 \mathrm{mM}$ phosphate buffer was prepared by dissolving $6.056 \mathrm{~g}$ of potassium dihydrogen ortho phosphate in $445 \mathrm{ml}$ of HPLC grade water. To this $55 \mathrm{ml}$ of $0.1 \mathrm{M}$ phosphoric acid was added and the $\mathrm{pH}$ was adjusted to 3.3 .

\section{Preparation of mobile phase}

The above prepared buffer and acetonitrile were mixed in the proportion of 50: $50 \mathrm{v} / \mathrm{v}$ and were filtered through $0.45 \mu \mathrm{m}$ nylon membrane filter and degassed by sonication

\section{Preparation of stock standard solutions and calibration plot}

Stock standard solutions containing $1.25,0.25,0.4,0.5,0.4,0.8$, and $1.5 \mathrm{mg} / \mathrm{ml}$ of HCTZ, ATEN, TELM, LOSA, VALS, OLME, and IRBE, respectively, were prepared by dissolving $12.5,25,40,50,40,80$, and $150 \mathrm{mg}$ of each in the mobile phase in a $100 \mathrm{ml}$ volumetric flask, respectively. It was then sonicated for 20 minutes and the eventual volume of the solutions was filled up to $100 \mathrm{ml}$ with methanol to get stock standard solutions. To construct calibration plots, the stock standard solutions were diluted with the mobile phase to prepare working solutions to get various concentrations ranging from 2.5-12.5, 5-25, 8-40, 5-50, 8-40, 16-80, and 30-150 $\mathrm{\mu g} / \mathrm{ml}$ for HCTZ, ATEN, TELM, LOSA, VALS, OLME, and IRBE, respectively.

\section{Sample preparation}

Twenty tablets of each sample Atenova-H ( $25 \mathrm{mg} / \mathrm{tab}$ ATEN), Cresar-H (40 mg/tab TELM), Hyzaar (50 mg LOSA), Valfect-H (40 mg VALS), Olmax-H (80 mg OLME), and Irovel-H (150 mg IRBE) and all these samples contains $12.5 \mathrm{mg} /$ tab of HCTZ were weighed accurately and average weight was determined. The contents were ground into a fine powder and the powder equivalent to 100 milligrams of the drug was transferred in to a $100 \mathrm{ml}$ of calibrated flask and dissolved in $70 \mathrm{ml}$ of mobile phase with vigorous shaking and extracted 2 times with $10 \mathrm{ml}$ portions of mobile phase and filtered through Whatman quantitative filter paper grade 41 into a $100 \mathrm{ml}$ volumetric flask and diluted up to the mark with the same. From the above filtrate, $1 \mathrm{ml}$ was further transferred to $100 \mathrm{ml}$ volumetric flask and made up to the mark with mobile phase to obtain $100 \mu \mathrm{g} / \mathrm{ml}$ sample solution in each case. These prepared solutions were utilized as stock sample solutions throughout the work. Subsequent dilution of this solution was prepared with mobile phase to furnish the above-mentioned concentrations. The diluted solutions were analyzed under optimized chromatographic conditions employed and chromatogram is shown in Fig. 1 .

\section{Method optimization}

When developing a novel method one of the most important goals is to accomplish a consistent reproducible separation. To acquire correct optimized HPLC conditions in the first instance in isocratic mode, copious trails were carried out by varying the different solvent mixtures

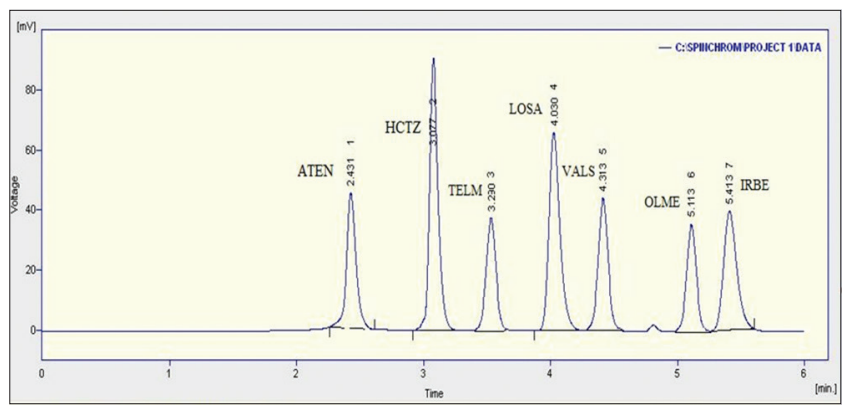

Fig. 1: A typical chromatogram showing the separation of atenolol and five angiotensin receptor blockade in the presence of hydrochlorothiazide mixture such as acetonitrile, methanol, HPLC grade water, with or without buffers in different combinations, $\mathrm{C}_{18}, \mathrm{C}_{8}$ columns, and flow rates as well as $\mathrm{pH}$ of were tested. Based on the nature of the drugs eventually $\mathrm{C}_{18}$ column was chosen as a stationary phase. Trials of optimization were made by varying one parameter at a time, keeping all other parameters constant. Ultimately decorous resolution, short run time, excellent peak shape, minimal peak tailing, and good reproducibility results were identified when an analytical column of $\mathrm{C}_{18}$ and a mixture of mobile phase consisting phosphate buffer with $\mathrm{pH} 3.3$ and acetonitrile in the ratio of $50: 50 \mathrm{v} / \mathrm{v}$, using a flow rate of $1 \mathrm{~mL} / \mathrm{min}$ are found to be suitable for most combinations. Optimized chromatographic conditions and system suitability parameters are shown in Table 1 . UV overlain spectra of the ATEN and five separations with HCTZ are shown in Fig. 2.

\section{Method validation}

The developed method of analysis was validated in pursuance of the guidelines of ICH Q2 (R1) [22,23] to examine the parameters such as system suitability, linearity, specificity, precision, accuracy, and robustness, limit of detection (LOD), and limit of quantitation (LOQ).

\section{RESULTS AND DISCUSSION}

In the present study drug solutions of $10 \mu \mathrm{g} / \mathrm{mL}$ concentration solution of ATEN, HCTZ, TELM, LOSA, VALS, OLME, and IRBE were separately prepared with the mobile phase. All the seven drugs were scanned over the range of $200-400 \mathrm{~nm}$ in spectrum mode by applying UV spectrophotometer. By studying the overlain spectra, it was observed that all these four drugs showed optimum absorbance at $230 \mathrm{~nm}$ and were selected for further study. Accordingly, system suitability parameters such as retention time, resolution, the number of theoretical plates, efficiency/meter, and tailing factor of the peaks were computed for the optimized chromatographic conditions. As a result retention time of $2.431,3.077,3.230,4.030,5.243,4.463$, and 5.563 minutes, resolution of --, 3.354, 2.615, 2.755, 2.844, 3.675, and 2.057 for ATEN, HCTZ, TELM, LOSA, VALS, OLME, and IRBE were obtained. Moreover, the plate number of $11987,12865,13379,14567$, 15231, 15625, and 16058 was obtained for ATEN, HCTZ, TELM, LOSA, VALS, OLME, and IRBE and tailing factors of 1.164, 1.146, 1.128, 1.164, $1.143,1.150$, and 1.132 were obtained for ATEN, HCTZ, TELM, LOSA, VALS, OLME, and IRBE, respectively. As the results obtained were within the satisfactory limits, this method is apt for the separation and estimation of the above said drugs. Summary of validation parameters linearity, specificity, precision, accuracy, LOD, and LOQ is shown in Table 2 .

Linearity

The purpose of this study is to verify that the detector response is directly proportional to the concentration of analyte in the sample. Linearity of developed method was determined by taking five different concentrations. The calibration curves for seven different drugs showed linearity over a concentration range of 5-25, 2.5-12.5, 8-40, 5-50, 8-40, 16-80, and 30-150 $\mu \mathrm{g} / \mathrm{mL}$ for ATEN, HCTZ, TELM, LOSA, VALS, OLME, and IRBE, respectively. In ATENOVA - H 25 mg tablet

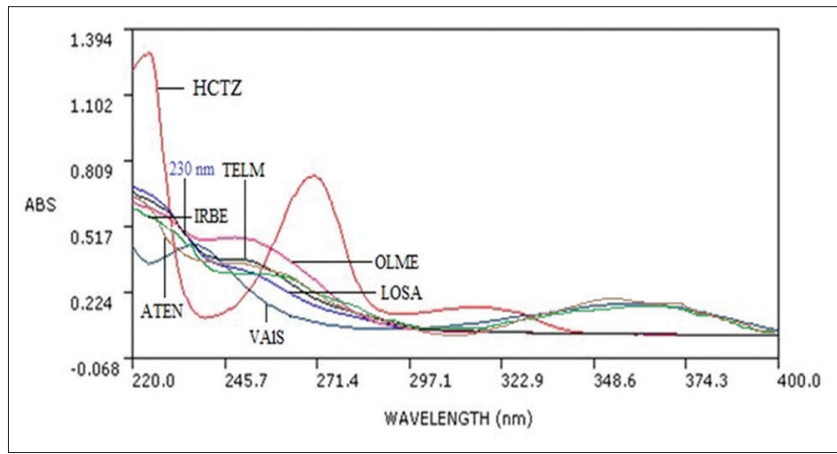

Fig. 2: Ultraviolet overlain spectra of the atenolol and five sartans with hydrochlorothiazide 
Table 1: Optimized chromatographic conditions and system suitability parameters

\begin{tabular}{|c|c|c|c|c|c|c|c|}
\hline Parameter & \multicolumn{7}{|c|}{ Chromatographic conditions for four sartans and hydrochlorothiazide } \\
\hline Instrument & \multicolumn{7}{|c|}{ Shimadzu LC-20AT prominence LC } \\
\hline Column & \multicolumn{7}{|c|}{ Welchrom $\mathrm{C} 18$ column $(4.6 \times 250 \mathrm{~mm}, 5 \mu \mathrm{m})$} \\
\hline Detector & \multicolumn{7}{|c|}{ Shimadzu SPD-20A prominence UV-VIS detector } \\
\hline Mobile phase & \multicolumn{7}{|c|}{$10 \mathrm{mM}$ phosphate buffer (pH 3.3): Acetonitrile 50:50, v/v } \\
\hline Flow rate & \multicolumn{7}{|c|}{$1 \mathrm{~mL} / \mathrm{min}$} \\
\hline wave length & \multicolumn{7}{|c|}{$\mathrm{UV}$ at $230 \mathrm{~nm}$} \\
\hline Run time & \multicolumn{7}{|c|}{6 minutes } \\
\hline \multirow[t]{2}{*}{ Injection volume } & \multicolumn{7}{|l|}{$20 \mu \mathrm{L}$} \\
\hline & ATEN & HCTZ & TELM & LOSA & VALS & OLME & IRBE \\
\hline Retention time (minute) & 2.431 & 3.077 & 3.230 & 4.030 & 5.243 & 4.463 & 5.563 \\
\hline Th.Pl (efficiency) & 11.987 & 12.865 & 13.379 & 14.567 & 15.231 & 15.625 & 16.058 \\
\hline Resolution & - & 3.354 & 2.615 & 2.755 & 2.844 & 3.675 & 2.057 \\
\hline Tailing factors & 1.164 & 1.146 & 1.128 & 1.164 & 1.143 & 1.150 & 1.132 \\
\hline
\end{tabular}

LC: Liquid chromatography, UV-VIS: Ultraviolet-visible, ATEN: Atenolol, OLME: Olmesartan, HCTZ: Hydrochlorothiazide, TELM: Telmisartan, LOSA: Losartan,

VALS: Valsartan, IRBE: Irbesartan

Table 2: Summary of validation parameters

\begin{tabular}{|c|c|c|c|c|c|c|c|}
\hline \multirow{2}{*}{$\begin{array}{l}\text { Formulation } \\
\text { (tablets) }\end{array}$} & \multirow[t]{2}{*}{ Composition } & \multirow{2}{*}{$\begin{array}{l}\text { Linearity } \\
(\mu \mathrm{g} / \mathrm{mL})\end{array}$} & \multirow{2}{*}{$\begin{array}{l}\text { LOD and } \\
\text { LOQ }(\mu \mathrm{g} / \mathrm{mL})\end{array}$} & \multirow{2}{*}{$\begin{array}{l}\text { Assay } \pm \text { SD } \\
(n=6)\end{array}$} & \multirow{2}{*}{$\begin{array}{l}\text { Mean \% recovery } \pm S D \\
(n=3)\end{array}$} & \multicolumn{2}{|l|}{ Precision } \\
\hline & & & & & & $\begin{array}{l}\text { Intra-day } \\
(n=6)(R S D \%)\end{array}$ & $\begin{array}{l}\text { Interday } \\
(n=3)(R S D \%)\end{array}$ \\
\hline \multirow[t]{2}{*}{ ATENOVA-H } & ATEN & $5-25$ & 0.331 and 1.02 & $99.95 \pm 1.24$ & $99.92 \pm 0.67$ & 0.343 & 0.342 \\
\hline & HCTZ & $2.5-12.5$ & 0.285 and 0.940 & $98.75 \pm 0.16$ & $99.82 \pm 0.12$ & 0.167 & 0.162 \\
\hline \multirow[t]{2}{*}{ Cresar-H } & TELM & $8-40$ & 0.565 and 1.86 & $99.97 \pm 1.12$ & $100.09 \pm 0.71$ & 0.127 & 0.167 \\
\hline & HCTZ & $2.5-12.5$ & 0.298 and 0.980 & $98.14 \pm 0.32$ & $100.05 \pm 0.16$ & 0.132 & 0.324 \\
\hline & HCTZ & $2.5-12.5$ & 0.296 and 0.981 & $99.14 \pm 0.31$ & $100.06 \pm 0.19$ & 0.188 & 0.182 \\
\hline \multirow[t]{2}{*}{ Valfect-H } & VALS & $8-40$ & 0.731 and 2.414 & $99.88 \pm 1.14$ & $100.02 \pm 0.16$ & 0.342 & 0.324 \\
\hline & HCTZ & $2.5-12.5$ & 0.297 and 0.980 & $98.18 \pm 0.42$ & $99.98 \pm 0.12$ & 0.127 & 0.432 \\
\hline \multirow[t]{2}{*}{ Olmax-H } & OLME & $16-80$ & 1.198 and 3.953 & $99.99 \pm 1.12$ & $100.45 \pm 0.40$ & 0.432 & 0.654 \\
\hline & HCTZ & $2.5-12.5$ & 0.295 and 0.980 & $99.15 \pm 0.12$ & $99.97 \pm 0.13$ & 0.168 & 0.324 \\
\hline \multirow[t]{2}{*}{ Irovel-H } & IRBE & $30-150$ & 1.220 and 4.026 & $100.15 \pm 1.30$ & $100.47 \pm 0.4$ & 0.467 & 0.324 \\
\hline & HCTZ & $2.5-12.5$ & 0.296 and 0.980 & $99.59 \pm 0.12$ & $99.96 \pm 0.15$ & 0.213 & 0.435 \\
\hline
\end{tabular}

LOD: Limit of detection, LOQ: Limit of quantitation, SD: Standard deviation, IRBE: Irbesartan, HCTZ: Hydrochlorothiazide, ATEN: Atenolol, OLME: Olmesartan,

LOSA: Losartan, VALS: Valsartan, TELM: Telmisartan

$5-25 \mu \mathrm{g} / \mathrm{mL}$ and $2.5-12.5 \mu \mathrm{g} / \mathrm{mL}$ for HCTZ; Cresar - H $40 \mathrm{mg}$ tablet 8-40 $\mu \mathrm{g} / \mathrm{mL}$ for TELM and 2.5-12.5 $\mu \mathrm{g} / \mathrm{mL}$ for HCTZ; for Hyzaar $50 \mathrm{mg}$ tablet $5-50 \mu \mathrm{g} / \mathrm{mL}$ for LOSA and $2.5-12.5 \mu \mathrm{g} / \mathrm{mL}$ for HCTZ; for Valent-H $80 \mathrm{mg}$ tablet $16-80 \mu \mathrm{g} / \mathrm{mL}$ for VALS and $2.5-12.5 \mu \mathrm{g} / \mathrm{mL}$ for HCTZ; Olmax-H $40 \mathrm{mg}$ tablet $8-40 \mu \mathrm{g} / \mathrm{mL}$ for OLME and $2.5-12.5 \mu \mathrm{g} / \mathrm{mL}$ for HCTZ; Irovel-H $150 \mathrm{mg}$ tablet $30-150 \mu \mathrm{g} / \mathrm{mL}$ for IRBE $2.5-12.5 \mu \mathrm{g} / \mathrm{mL}$ for HCTZ and the correlation coefficients were calculated from the linear regression analysis and it was found to be above 0.9998 in all cases. The obtained results were satisfactory as there exist a significant correlation between concentrations of each drug and their peak areas. The $\mathrm{r}^{2}$ (correlation coefficients) regression was found almost equal to one in all cases.

\section{Specificity}

The purpose of this study is to evaluated by determine the effect of excipients, additives present in the formulations interfered with the analysis or not. As per the ICH guidelines, to test the specificity of the developed method a combination of pure drug samples with proper excipients were injected to the system for quantifying each drug individually and also in combination of two drugs, namely, HCTZ with ATEN and HCTZ with TELM, HCTZ with LOSA, HCTZ with VALS, HCTZ with OLME, and HCTZ with IRBE. In the same way blank solution with only commonly utilized excipients and synthetic mixture solutions were also injected separately. Peak responses for analyte and the blank were compared with each appropriate drug. The present study shows that there is no commonly used excipients are interfering with the drug peaks. Thus, the method clearly proves to be specific for determining the above said drugs.

\section{Precision}

To check the reproducibility of the method, the precision of the analytical method was determined by using intraday and interday studies. Triplicate samples of standard quality were taken in varying concentration levels and estimated for the intraday and interday precision of the developed method. For repeatability and intermediate precision the relative standard deviation (RSD\%) values for all the drugs were calculated and RSD\% of all the combined drugs were shown $<2 \%$ which explains that the current method is precise.

\section{Accuracy}

Accuracy of the present method was evaluated by combining the known quantity of pure standard drugs to pre analyzed samples at three different levels mostly $80 \%, 100 \%$, and $120 \%$. Then, the recovery levels were observed obviously. The above-mentioned solutions were again prepared and analyzed in triplicate carefully. The same procedure was followed for all the individual drugs and also for drug combinations such as HCTZ with ATEN and HCTZ with TELM, HCTZ with LOSA, HCTZ with VALS, HCTZ with OLME, and HCTZ with IRBE and RSD\% calculated was also known to be $<2 \%$ for each of the drugs. As per ICH guidelines the $\%$ recovery must be between $98 \%$ and $102 \%$.

\section{Robustness}

Small, experimental conditions such as flow rate, detection wavelength, and mobile phase composition are deliberately changed. It was observed in fact no significant variations in these parameters indicating that the method is robust. The RSD\% values obtained in all the cases are $<2 \%$, hence this method is robust. Table 3 summarizes the robustness, data. 


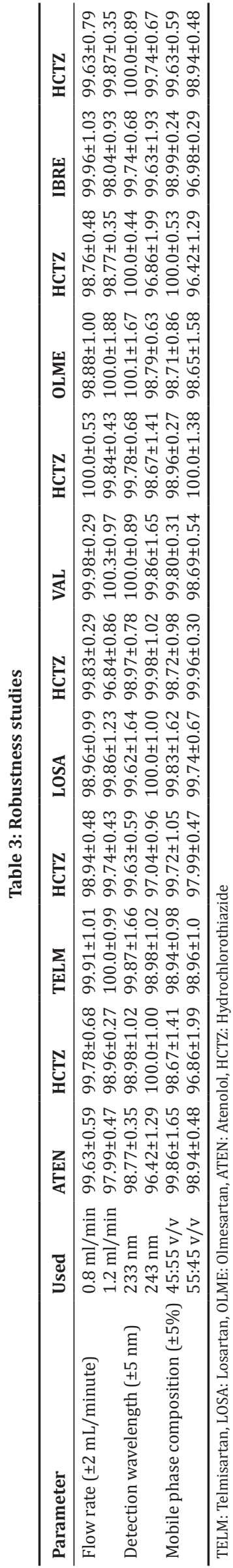

\section{LOD and LOQ}

Sensitivity of the analytical method is evaluated by the LOD and LOQ. $L O D=3.3$ (SD)/S and LOQ=10 (SD)/S. The LOD and LOQ results for combined drugs such as ATEN with HCTZ, TELM with HCTZ, LOSA with HCTZ, VALS with HCTZ, OLME with HCTZ, and IBRE with HCTZ were found to be $0.331 \mu \mathrm{g} / \mathrm{mL}$ and $1.026 \mu \mathrm{g} / \mathrm{mL}, 0.285 \mu \mathrm{g} / \mathrm{mL}$ and $0.940 \mu \mathrm{g} / \mathrm{mL} ; 0.565 \mu \mathrm{g} / \mathrm{mL}$ and $1.86 \mu \mathrm{g} / \mathrm{mL}, 0.298 \mu \mathrm{g} / \mathrm{mL}$ and $0.980 \mu \mathrm{g} / \mathrm{mL} ; 0.197 \mu \mathrm{g} / \mathrm{mL}$ and 0.650 $\mu \mathrm{g} / \mathrm{mL}, 0.296 \mu \mathrm{g} / \mathrm{mL}$ and $0.981 \mu \mathrm{g} / \mathrm{mL} ; 0.731 \mu \mathrm{g} / \mathrm{mL}$ and $2.414 \mu \mathrm{g} / \mathrm{mL}$, $0.297 \mu \mathrm{g} / \mathrm{mL}$ and $0.980 \mu \mathrm{g} / \mathrm{mL} ; 1.198 \mu \mathrm{g} / \mathrm{mL}$ and $3.953 \mu \mathrm{g} / \mathrm{mL}, 0.295$ $\mu \mathrm{g} / \mathrm{mL}$ and $0.980 \mu \mathrm{g} / \mathrm{mL} ; 1.220 \mu \mathrm{g} / \mathrm{mL}$ and $4.026 \mu \mathrm{g} / \mathrm{mL}$, and 0.296 $\mu \mathrm{g} / \mathrm{mL}$ and $0.980 \mu \mathrm{g} / \mathrm{mL}$, respectively. The lowest LOD and LOQ values showed that the method is more sensitive.

\section{Assay}

The developed method was finally applied for quantification of marketing formulation. Satisfactory results have been obtained. The mean assay values for ATEN with HCTZ, TELM with HCTZ, LOSA with HCTZ, VALS with HCTZ OLME with HCTZ, and IBRE with HCTZ combination of drugs were found to be $99.95 \pm 1.24$ and $98.75 \pm 0.16$; $99.97 \pm 1.12$ and $98.14 \pm 0.32$; $99.87 \pm 0.12$ and $99.14 \pm 0.31$; $99.88 \pm 1.14$ and $98.18 \pm 0.42$; $99.99 \pm 1.12$ and $99.15 \pm 0.12 ; 100.15 \pm 1.30$ and $99.59 \pm 0.12$, respectively. The mean assay values were in good agreement with the label claim (Table 2). Hence, by the developed method all the specified drugs were recovered perfectly pharmaceutical dosage forms. Therefore, the method developed was found to be properly suitable for the estimation of the marketed formulations.

\section{CONCLUSION}

A simple, precise, accurate, and sensitive isocratic RP-HPLC method have been developed for simultaneous determination of HCTZ, ATEN, TELM, LOSA, VALS, OLME, and IRBE in bulk and combined tablet dosage forms. Statistical analysis lucidly proves that this method is fast, cost effective, highly efficient, and robust than the existing methods hitherto. In addition, to that, the method is free from interferences of the excipients and additives used in the preparation of the above-said combination formulations. This novel method separated all the abovesaid drugs in 4 minutes and total run time of just 6 minutes and it is also feasible for analysis of said angiotensin receptor blockades with HCTZ in their formulations in a single run without changing the mobile phase composition and chromatographic conditions. Hence, it is correct to conclude that it is effectively used for the application of all the abovesaid drugs individually or in binary combinations in quality control laboratories.

\section{ACKNOWLEDGMENTS}

The authors are thankful to Hetero Labs for providing the samples. We are highly grateful to Dr. L. Rathaiah, Honorable Chairman, Vignan group of institutions and Prof. P. Srinivasa Babu Principal, Vignan Pharmacy College, Vadlamudi, Guntur, for providing the necessary laboratory facilities to carry out this investigation.

\section{REFERENCES}

1. Bari S, Sathe S, Jain P, Surana S. Spectrophotometric method for simultaneous estimation of atenolol in combination with losartan potassium and hydrochlorothiazide in bulk and tablet formulation. J Pharm Bioallied Sci 2010;2(4):372-5.

2. Hillaert S, van den Bossche W. Simultaneous determination of hydrochlorothiazide and several angiotensin-II-receptor antagonists by capillary electrophoresis. J Pharm Biomed Anal 2007;31(2):329-39.

3. Ahmed S, Atia NN, Mohamed NA. Dual separation mode for simultaneous determination of antihypertensive drug combinations by high-performance liquid chromatography. Talanta 2011;84(3):666-72.

4. Ravisankar P, Devi MS, Ravali B, Tejaswini K, Balaji D, Babu PS Rapid simultaneous separation of four sartans by isocratic RP-HPLC method: Application to determination of olmisartan in pharmaceutical dosage form. J Chem Pharm Sci 2015;8(1):61.

5. Yadav SS, Rao JR. RP-HPLC method for simultaneous estimation of losartan, hydrochlorothiazide and amlodipine in tablet dosage form. 
Asian J Pharm Clin Res 2014;7(1):137-40.

6. Ravisankar P, Swathi J, Kumar KV, Babu PS. Novel RP-HPLC method for simultaneous determination of olmesartan medoxomil, amlodipine besylate and hydrochlorothiazide in tablet dosage form. Int $\mathrm{J}$ Biol Pharm Res 2014;5(12):927-36.

7. Kumar MS, Rao JV. Development and validation of stability indicating RP-HPLC method for simultaneous determination of telmisartan and amlodipine in combined dosage form. Asian J Pharm Clin Res 2014;7(1):32-5

8. Ravisankar R, Vineela C, Koushik OS, Babu PS. Novel simultaneous separation and quantitative determination of telmisartan, losartan, olmesartan and irbesartan in presence of hydrochlorothiazide by isocratic RP-HPLC. Adv J Pharm Life Sci Res 2015;3(4):1-18.

9. Tian DF, Tian XL, Tian T, Wang ZY, Mo FK. Simultaneous determination of valsartan and hydrochlorothiazide in tablets by RPHPLC. Indian J Pharm Sci 2008;70(3):372-4.

10. Kollipara S, Bende G, Bansal Y, Saha R. Stability-indicating reversedphase liquid chromatographic method for simultaneous determination of losartan potassium and ramipril in tablets. Indian $\mathrm{J}$ Pharm Sci 2012;74(3):201-10.

11. Wankhede SB, Tajne MR, Gupta KR, Wadodkar SG. RP-HPLC method for simultaneous estimation of telmisartan and hydrochlorothiazide in tablet dosage form. Indian J Pharm Sci 2007;69(2):298-300.

12. Ravisankar P, Manjusha K, Sri VL, Kumar BV, Rajyalakshmi K, Babu PS. Quantitative estimation of four sartans in presence of hydrochlorothiazide in pharmaceutical preparations by high performance liquid chromatography. Br J Pharm Res 2016;11(4):1-15.

13. Rane VP, Patil KR, Shangshetti JN, Yeole RD, Shinde DB. Stabilityindicating LC method for the determination of olmesartan in bulk drug and in pharmaceutical dosage form. Chromatographia 2009;69(1-2):169-73.

14. Patel UM, Chokshi AB, Desai PR. Development and validation of RPHPLC method for determination of hydrochlorothiazide, olmesartan medoxomil and their related substances in combined tablet dosage form. Int J Pharm Pharm Sci 2014;6(9):318-23.

15. Indrani B, Ghosh SK. Development and validation of stability indicating RP-HPLC method for the determination of atenolol and hydrochlorthiazide in combined solid dosage form. Int J Pharm Pharm Sci 2015;7(2):489-92.

16. Shetty SK, Surendranath KV, Radhakrishnanand P. Quantitative application to a polypill by the development of stability indicating LC method for the simultaneous estimation of aspirin, atorvastatin, atenolol and losartan potassium. Am J Anal Chem 2010;2:59-69.

17. Kristoffersen L, Øiestad EL, Opdal MS, Krogh M, Lundanes E, Christophersen AS. Simultaneous determination of 6 beta-blockers, 3 calcium-channel antagonists, 4 angiotensin-II antagonists and 1 antiarrhythmic drug in post-mortem whole blood by automated solid phase extraction and liquid chromatography mass spectrometry. Method development and robustness testing by experimental design. J Chromatogr B Analyt Technol Biomed Life Sci 2007;850(1-2): 147-60.

18. Li H, Wang Y, Jiang Y, Tang Y, Wang J, Zhao L, et al. A liquid chromatography/tandem mass spectrometry method for the simultaneous quantification of valsartan and hydrochlorothiazide in human plasma. J Chromatogr B Analyt Technol Biomed Life Sci 2007;852(1-2):436-42.

19. Tutunji LF, Tutunji MF, Alzoubi MI, Khabbas MH, Arida AI Simultaneous determination of irbesartan and hydrochlorothiazide in human plasma using HPLC coupled with tandem mass spectrometry: Application to bioequivalence studies. J Pharm Biomed Anal 2010;51(4):985-90

20. Vaidya VV, Roy SM, Yetal SM, Joshi SS, Parekh SS. LC-MS-MS determination of olmesartan in human plasma. Chromatographia 2008;67(1-2):147-50.

21. Liu F, Zhang J, Gao S, Guo Q. Simultaneous determination of hydrochlorothiazide and valsartan in human plasma by liquid chromatography/tandem mass spectrometry. Anal Lett 2008;41(8):1348-65.

22. Ravisankar P, Gowthami S, Rao GD. A review on analytical method development. Indian J Res Pharm Biotechnol 2014;2(3):1183-95.

23. International Conference on Harmonization Q2 (R1). Validation of Analytical Procedures: Text and Methodology. Geneva: International Conference on Harmonization; 2005. p. 1-17. 